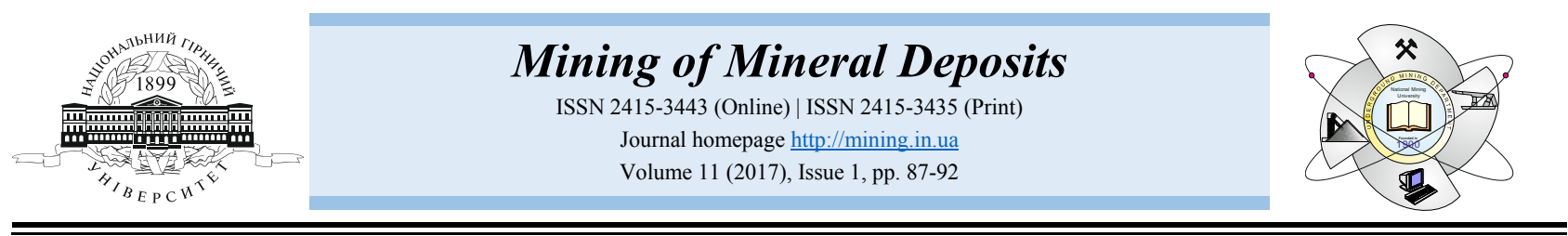

UDC 622.267 .7

https://doi.org/10.15407/mining11.01.087

\title{
TECHNOLOGY OF MICRO-CEMENT INJECTION OF DESTROYED AND FRACTURED MASSIF AT ORLOVSKY MINE
}

\author{
L. Krupnik ${ }^{1}$, Yu. Shaposhnik ${ }^{2}$, S. Shaposhnik ${ }^{3}$, A. Konurin ${ }^{2 *}$ \\ ${ }^{I}$ Department of Mining and Metallurgical Machinery and Equipment, Kazakh National Research Technical University named after \\ K.I. Satpayev, Almaty, Republic of Kazakhstan \\ ${ }^{2}$ Laboratory of Physical and Technical Geotechnology, Institute of Mining named after N.A. Chinakal of the Siberian Branch of the \\ Russian Academy of Sciences, Novosibirsk, Russia \\ ${ }^{3}$ Department of Geomechanics and Mining, D. Serikbaev East-Kazakhstan State Technical University, Ust-Kamenogorsk, Republic of \\ Kazakhstan \\ *Corresponding author: e-mail anton.konurin@gmail.com,tel.+73832053030
}

\section{ТЕХНОЛОГІЯ ІН'ЄКЦІЮВАННЯ МІКРОЦЕМЕНТАМИ ЗРУЙНОВАНОГО ТА СИЛЬНОТРІЩІНУВАТОГО МАСИВУ НА ОРЛІВСЬКІЙ ШАХТІ}

\author{
Л. Крупник ${ }^{1}$ Ю. Шапошник ${ }^{2}$, С. Шапошник ${ }^{3}$, А. Конурин ${ }^{2 *}$ \\ ${ }^{l}$ Кафедра гірничих і металургійних машин та обладнання, Казахський національний дослідний технічний університет \\ ім. К.І. Сатпаєва, Алмати, Республіка Казахстан \\ ²Лабораторія фізико-технічних геотехнологій, Інститут гірничої справи ім. М.А. Чинакала Сибірського відділення Російської \\ академії наук, Новосибірськ, Росія \\ ${ }^{3}$ Кафедра геомеханіки та гірничої справи, Східно-Казахстанський державний технічний університет ім. Д. Серикбаєва, \\ Усть-Каменогорськ, Республіка Казахстан \\ *Bідповідальний автор: e-mail anton.konurin@gmail.com, тел.+73832053030
}

\begin{abstract}
Purpose. Research into the method of strengthening destroyed and fractured rock massif by micro-cement injection during rock driving at Orlovsky mine of "Vostoktsvetmet" LLP.

Methods. In situ researches of massif strengthening by cement slurry were performed. Monitoring of injection works implementation was carried out by control tests of reinforced rock cores. Phase composition of core samples (crushed probe) was defined on the X-ray diffractometer. Method of raster electron microscopy with energy dispersive microanalysis was used to determine the surface morphology and local elemental analysis of core samples. The material and labor costs related to works on strengthening of rock massif were calculated.

Findings. Massif strengthening method was studied. MasterRoc MP 650 micro-cement produced by BASF Construction Chemicals Ltd with addition of $1-2 \%$ of cement weight of Rheobuild 2000PF was used as cement slurry. The uniformity of the working contour in tunnel faces was observed after the third cycle of works on rocks injection. Unsafe working conditions for packer installation have been revealed. It was recommended to carry out pilot tests of tunneling technology in destroyed and fractured massif using the two-component organic-mineral resin "Blocksil" and long selfwedging packers with injection tubes.
\end{abstract}

Originality. We established peculiarities of implementing technology of strengthening destroyed and fractured rock massif by micro-cement injection. Quantitative indicators of micro-cement content in the injected rock massif were identified.

Practical implications. Technology of strengthening destroyed and fractured rock massif by micro-cement injection was developed and tested at Orlovsky mine.

Keywords: technology of massif injection, micro-cement, packers with injection tubes, place driving, rock massif stability

\section{INTRODUCTION}

Exploitation of Orlovsky deposit is characterized by increasingly complex geological conditions, as the growing depth of the deposit development leads to the appearance of numerous locations of stress concentration, where dynamic forces cause local fall out and destruction of rocks. As the experience of mining companies shows, injection of such bonding compositions as synthetic resins or similar substances into the rock massif allows to increase the resistance of the massif to tensile stress. Static and dynamic loads cause the appearance of a more 
uniform stress field due to cracks filling in different directions and systems. There is a gradual concreting of a massif in the marginal fractured zone of inelastic deformation, and deblocking of the massif and its sections. In addition, the number of characteristic points where a massif is in linear or plane stress, reduces, i.e., the number of stress locations diminishes (Butenko, Kara, Salnikov, \& Pihovich, 1978; Kiziyarov, 2004; Kiziyarov, 2012; Klimchuk, 2007; Feofanov, 2009).

Basic requirements for the injection works on strengthening rocks are given in "Rules of industrial safety...” (Pravila obespecheniya ..., 2014).

\section{METHODOLOGY}

Injection into the rock massif was conducted at Orlovsky mine in the access to the $12^{\text {th }}$ layer of $12 \mathrm{C}$ block, 12 horizon, and in the collecting airway of $15^{\text {th }}$ horizon during the process of mining in the abandoned and fractured rock massif.

Technology of massif injection in Orlovsky mine conditions is as follows. Holes $41-43 \mathrm{~mm}$ in diameter were drilled by rotary perforators in the working of $12.8 \mathrm{~m}^{2}$ section on the mesh spacing $0.5 \mathrm{~m}$. 19 holes of $3 \mathrm{~m}$ depth were drilled on the top and sides of the working in one stope (Fig. 1). In total, 4 cycles of injections were carried out in the collecting airway, and 8 cycles were carried out in the access to the $12^{\text {th }}$ layer.

(a)

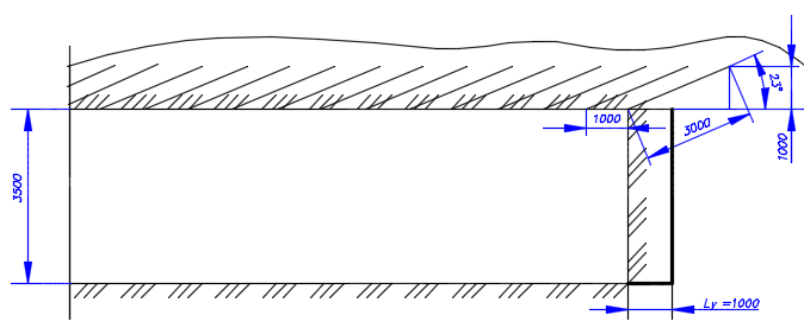

(b)

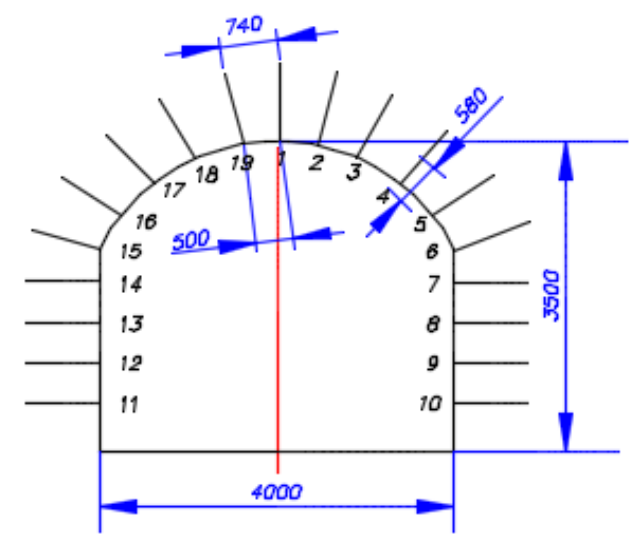

Figure 1. The scheme of holes drilling for massif injection in Orlovsky mine conditions: (a) longitudinal section; (b) cross-section

Heading advance did not exceed $1.2-1.5 \mathrm{~m}$ for $3 \mathrm{~m}$ deep injection holes drilled at the angle of $23^{\circ}$. The distance between the rows of injection holes did not exceed $1.5 \mathrm{~m}$.
In total, 93 holes were drilled in the face of the collecting airway for injection of rock massif by microcement, while solution oozing through cracks was observed in 67 boreholes. 108 holes were drilled in the face of the access to the $12^{\text {th }}$ layer for rock massif injection, oozing of micro-cement through cracks was observed in 26 boreholes. The distance from the ends of the hole to the design contour of the working was $1.0 \mathrm{~m}$. The radius of the solution spreading was $0.56 \mathrm{~m}$ with the coefficient of fractured rock massif 0.1 and the superficial inclined injection. Each hole was thoroughly washed and flushed after its drilling. Metal expanding valvular injector ("packer") was installed into the drilled hole. Tamping was performed in two stages: operating tamping and test tamping. Operating tamping was carried out by injection of the solution under the working pressure of $5.5 \mathrm{MPa}$ in the operating boreholes. Test tamping was carried out by the flow of injection solution through the test boreholes under the working pressure up to $6.5 \mathrm{MPa}$. The operating and test boreholes were distributed along the perimeter of the working in a next but one manner, i.e. the first hole is operating, the $2^{\text {nd }}$ hole is being tested, the $3^{\text {rd }}$ hole is operating, the $4^{\text {th }}$ hole is being tested, etc.

The solution was being injected up to the moment when the absorption of the solution stopped at a predetermined operating pressure, or when the solution appeared or leaked through the test holes. Each hole was kept under specified pressure for 5 minutes. In the case of plugging solution appearance in the test boreholes, the packer was installed there, and then, after operation stage, injection of the second stage of tamping (test tamping) was made. The solution was injected with maximum intensity in order to fill the caves in the shortest possible time.

MasterRoc MP 650 micro-cement of BASF company was used as the plugging solution with the addition of Rheobuild 2000PF ( $1-2 \%$ of cement mass). MasterRoc MP 650 micro-cement is made on the basis of portland cement with a low content of threecalcium aluminate $(0-2.5 \%)$ and a low content of alkali $(0.3-0.5 \%)$ by way of its additional grinding to the fineness of $6500 \mathrm{~cm}^{2} / \mathrm{g}$. It does not contain particles larger than 40 microns, and no less than $95 \%$ of its mass is composed of particles smaller than 16 microns. Watercement ratio (by weight) is in the range $0.5-1.0$.

Consumption of materials by one hole is:

- MasterRoc MP 650 micro-cement - $12.7-10.41 \mathrm{~kg}$;

- Rheobuild 2000PF additive $-0.1568-0.1915 \mathrm{~kg}$;

- solution consumption by a hole $3 \mathrm{~m}$ long $-13.8-16.91$.

The values of strength of unalloyed cement slurries according to measurements of BASF Construction Chemicals (Switzerland) Ltd are shown in Figure 2.

Departing from (STO NOSTROY 2.3.18-2011, 2011), monitoring of injection works must be carried out by control tests to determine the results of massif strengthening by injection, in particular, by testing core samples of reinforced rock, as well as by assessment of conformity of the obtained results with the design requirements. The regulations (STO 17466563-001-2011, 2011) point out that the number of test boreholes must constitute approximately $3-5 \%$ of the total number of injection holes, in our case - within the range of $3-5$ items. 


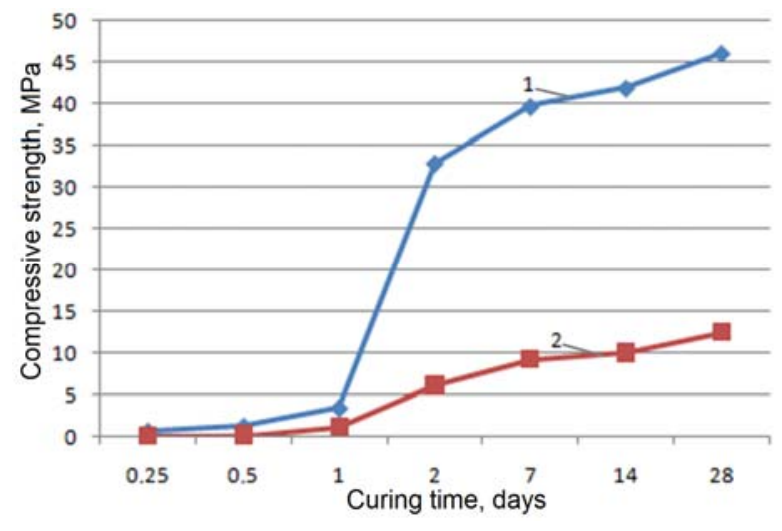

Figure 2. Characteristic dependence of strength development of undoped MasterRoc MP 650 slurries for a watercement ratio-0.5:1.0 $(1-W / C=0.5 ; 2-W / C=1.0)$

\section{RESULTS AND DISCUSSION}

Coring was made from the boreholes drilled within the interval of the third cycle of injection works $\left(1^{\text {st }}-\right.$ in the southern edge; $2^{\text {nd }}-$ in the top, $3^{\text {rd }}-$ in the northern edge in the rocks area injection) for the purpose of a representative and objective investigation of reinforced rock massif in the collecting airway drift of $15^{\text {th }}$ horizon of "Novaia" deposit of North ore body. The results of compressive strength determination of the drilled core samples are shown in Table 1.

Table 1. Compressive strength of the drilled core samples at the top and the edges of the airway drift of $15^{\text {th }}$ horizon

\begin{tabular}{ccc}
\hline $\begin{array}{c}\text { Number } \\
\text { of a hole }\end{array}$ & $\begin{array}{c}\text { The cut-off } \\
\text { sampling, } \mathrm{m}\end{array}$ & $\begin{array}{c}\text { Compressive strength } \\
\text { of the core samples, MPa }\end{array}$ \\
\hline 1 (in the & $1-2$ & 59.61 \\
southern edge) & $2-3$ & 65.79 \\
& $0-1$ & 55.33 \\
(at the top) & $1-2$ & 45.98 \\
3 (in the & $1-2$ & 61.86 \\
northern edge) & $2-3$ & 41.88 \\
\hline
\end{tabular}

The following conclusions can be drawn from the data presented in Table 1. The strength of the destroyed massif of host rocks at the top and the northern edge of the airway drift of $15^{\text {th }}$ horizon decreases as the distance from the rock injection area increases (respectively, by 17 and 32\%). Higher compressive strength of the drilled core samples is observed close to the contour of the airway drift, which indicates its hardening by microcement. However, in the southern edge of the airway drift, the opposite is true. Compressive strength of the drilled core is increased by $10 \%$ at a distance from the contour of working.
This can be explained by the fact that the host rocks in the southern edge were less fractured, thus the massif received a smaller volume of the plugging solution closer to the working contour and a bigger volume of the plugging solution was injected at a distance of $2.5-3.0 \mathrm{~m}$ from the contour of working.

The drilled core from the rock massif was ground on a vibrating grinder to $0.02 \mathrm{~mm}$ fineness (preliminary crushing was carried out on jaw and roll crushers) in order to identify quantitative indicators of micro-cement content in the injected rock massif. Output weight of the sample was up to $250 \mathrm{~g}$, the phase composition of micro-cement was identified and its content in the crushed material of the drilled core was determined. Phase composition of the core samples (crushed probe) was defined on the X-ray diffractometer. X-ray diffraction method for the X-ray diffractometer (X'Pert PRO MPD) was used to conduct semi-quantitative determination of the phase composition.

The chemical composition of micro-cement is as follows (the content of the main components, \%): $\mathrm{SiO}_{2}-$ $17.92 \% ; \mathrm{Al}_{2} \mathrm{O}_{3}-5.93 \% ; \mathrm{CaO}-63.84 \% ; \mathrm{MgO}-4.24 \%$; $\mathrm{P}_{2} \mathrm{O}_{3}-0.025 \% ; \mathrm{S}-0.79 \% ; \mathrm{H}_{2} \mathrm{O}-0.63 \%$; others $-6.63 \%$. Taking into account the results of phase composition, it was revealed that the content of $\mathrm{Ca}(\mathrm{OH})_{2}$ and $\mathrm{SiO}_{2}$ in the southern edge of the drift (borehole No 1) is much higher than that in the northern edge and the top (40, 6 and $6 \%$ respectively). The data related to the phase composition are in good agreement with the core material strength characteristics, in particular, the southern edge of working (borehole No 1) has higher strength characteristics at a distance of $2.5-3.0 \mathrm{~m}$.

The method of raster electron microscopy with energy dispersive microanalysis done with the help of the scanning electron microscope JSM-6390LV was used to determine the surface morphology and local elemental analysis of the core samples. The resulting overview photographs of the prepared samples surface $(\leq \times 3000)$ with the points for determination of the elemental composition are shown in Figure 3.

Cracks show as white, gray or black color in the pictures. The massif of host rocks has a dark color. The content of $\mathrm{Ca}$ along the cracks in sample $1-3-1$ was 0.2 and $6.17 \%$ compared with the content of $\mathrm{Ca}$ in the massif of host rocks $0.2 \%$; in sample $1-3-2$ it was 0.32 and $0.25 \%$; in sample $2-3-1$ it was 0.22 and $0.1 \%$; in sample $3-3-1$ it was $0.12 \%$ and $0.13 \%$.

Thus, the content of $\mathrm{Ca}$ in the cracks is several times higher than that in host rocks, which is likely to testify to the higher content of micro-cement in the cracks of the rock massif. The cost of materials for the works on the preliminary hardening of rocks ${ }^{*}$ is shown in Table 2.

Table 2. The cost of materials used in the preliminary rocks strengthening

\begin{tabular}{lc}
\hline \multicolumn{1}{c}{ Materials } & Unit cost of materials, taking into account the value added tax, U.S. dollars \\
\hline Micro-cement Master Roc MP 650, kg & 1.53 \\
Plasticizer Master Rheobuild 2000PF, kg & 4.45 \\
Expanding packer, pcs. & 39.5 \\
Pressure hose Ø $25 \mathrm{~mm}, \mathrm{~m}$ & 11.8 \\
High pressure hose Ø $10-12 \mathrm{~mm}, \mathrm{~m}$ & 7.8 \\
Gates, respectively, Ø 50, 25 and $15 \mathrm{~mm}$, pcs. & $43.7 ; 21.5 ; 15.5$ \\
Cable KG $3 \times 16-1 \times 6, \mathrm{~m}$ & 3.2 \\
Cable KG $3 \times 4-1 \times 1,5, \mathrm{~m}$ & 1.4 \\
Lighting apparatus AOSH-5, pcs. & 2637.6 \\
LED spotlight, pcs. & 446.8 \\
\hline
\end{tabular}

* Does not include the cost of purchasing or renting GP-40 mine performance injection pump 
(a)
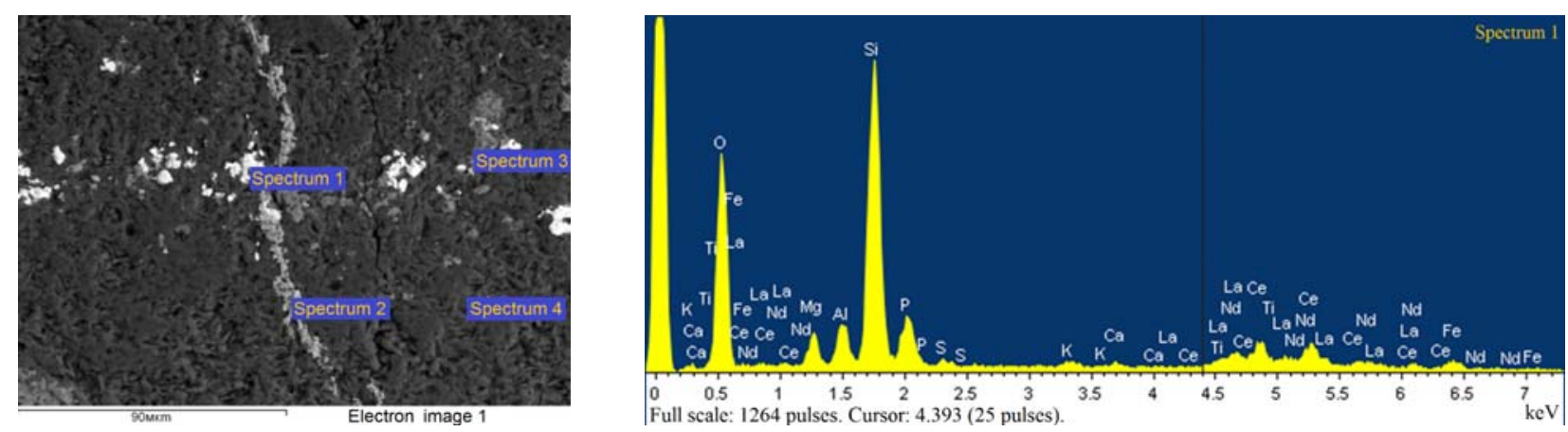

\begin{tabular}{|c|c|c|c|c|c|c|c|c|c|c|c|c|c|}
\hline \multirow{2}{*}{$\begin{array}{l}\text { Number of } \\
\text { spectrum }\end{array}$} & \multicolumn{13}{|c|}{ Designation of elements } \\
\hline & $\mathrm{O}$ & $\mathrm{Mg}$ & $\mathrm{Al}$ & $\mathrm{Si}$ & $\mathrm{P}$ & $\mathrm{S}$ & $\mathrm{K}$ & $\mathrm{Ca}$ & $\mathrm{Ti}$ & $\mathrm{Fe}$ & $\mathrm{La}$ & $\mathrm{Ce}$ & $\mathrm{Nd}$ \\
\hline 1 & 45.83 & 2.71 & 2.98 & 20.37 & 4.35 & 0.52 & 0.47 & 0.32 & 0.90 & 2.05 & 5.78 & 10.13 & 3.59 \\
\hline 2 & 39.25 & 2.50 & 2.62 & 17.46 & - & 18.62 & 0.49 & 0.00 & - & 19.06 & - & - & - \\
\hline 3 & 58.05 & 2.38 & 2.86 & 14.21 & - & - & 0.36 & 0.25 & 20.71 & 1.18 & - & - & - \\
\hline 4 & 56.65 & 3.44 & 3.43 & 33.79 & - & - & 0.44 & - & 0.44 & 1.80 & - & - & - \\
\hline Max & 58.05 & 3.44 & 3.43 & 33.79 & 4.35 & 18.62 & 0.49 & 0.32 & 20.71 & 19.06 & 5.78 & 10.13 & 3.59 \\
\hline Min & 39.25 & 2.38 & 2.62 & 14.21 & 4.35 & 0.52 & 0.36 & 0.00 & 0.44 & 1.18 & 5.78 & 10.13 & 3.59 \\
\hline
\end{tabular}

(b)
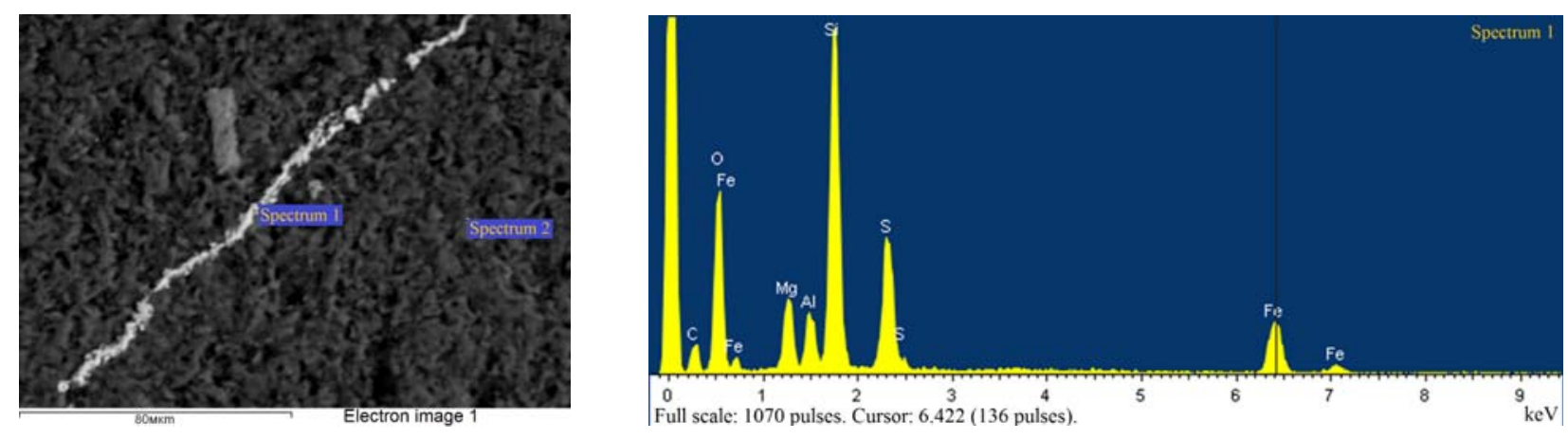

\begin{tabular}{|c|c|c|c|c|c|c|}
\hline \multirow{2}{*}{ Number of spectrum } & \multicolumn{6}{|c|}{ Designation of elements } \\
\hline & $\mathrm{O}$ & $\mathrm{Mg}$ & $\mathrm{Al}$ & $\mathrm{Si}$ & $\mathrm{S}$ & $\mathrm{Fe}$ \\
\hline 1 & 43.90 & 5.90 & 3.76 & 22.79 & 10.06 & 13.59 \\
\hline 2 & 52.80 & 9.11 & 5.29 & 28.60 & - & 4.19 \\
\hline Max & 52.80 & 9.11 & 5.29 & 28.60 & 10.06 & 13.59 \\
\hline Min & 43.90 & 5.90 & 3.76 & 22.79 & 10.06 & 4.19 \\
\hline
\end{tabular}

(c)
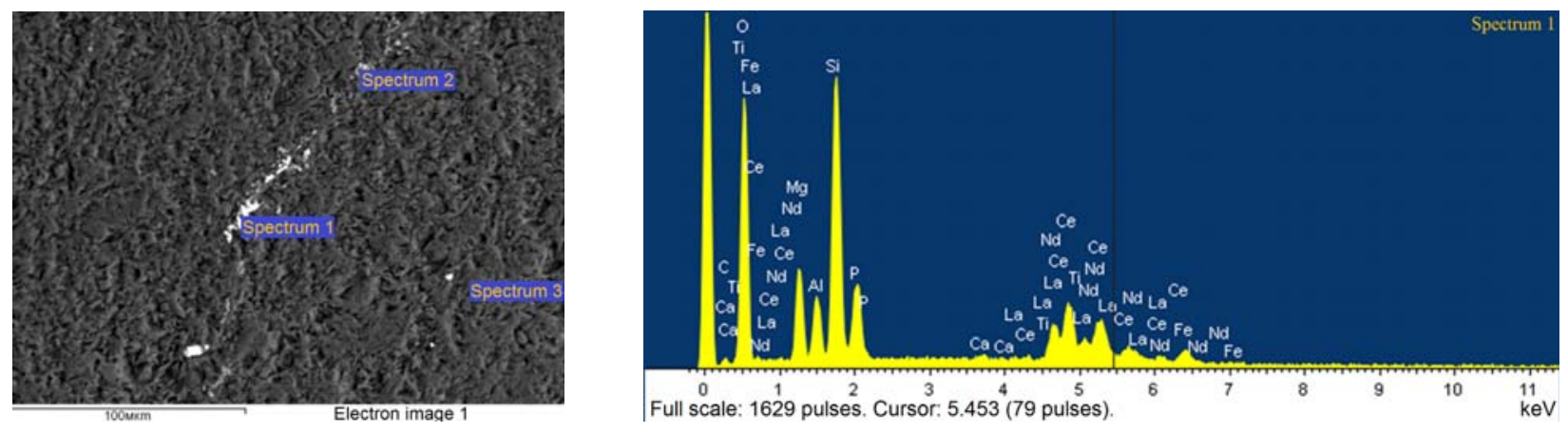

\begin{tabular}{|c|c|c|c|c|c|c|c|c|c|c|c|}
\hline \multirow{2}{*}{$\begin{array}{l}\text { Number of } \\
\text { spectrum }\end{array}$} & \multicolumn{11}{|c|}{ Designation of elements } \\
\hline & $\mathrm{O}$ & $\mathrm{Mg}$ & $\mathrm{Al}$ & $\mathrm{Si}$ & $\mathrm{P}$ & $\mathrm{Ca}$ & $\mathrm{Ti}$ & $\mathrm{Fe}$ & $\mathrm{La}$ & $\mathrm{Ce}$ & $\mathrm{Nd}$ \\
\hline 1 & 37.81 & 6.04 & 3.62 & 15.31 & 5.04 & 0.32 & 0.22 & 2.07 & 9.65 & 16.18 & 3.73 \\
\hline 2 & 53.28 & 5.80 & 5.83 & 23.80 & 0.12 & 2.59 & 0.18 & 3.85 & 1.37 & 2.59 & 0.59 \\
\hline 3 & 57.12 & 7.94 & 4.85 & 27.36 & - & - & - & 2.72 & - & - & - \\
\hline $\operatorname{Max}$ & 57.12 & 7.94 & 5.83 & 27.36 & 5.04 & 2.59 & 0.22 & 3.85 & 9.65 & 16.18 & 3.73 \\
\hline Min & 37.81 & 5.80 & 3.62 & 15.31 & 0.12 & 0.32 & 0.18 & 2.07 & 1.37 & 2.59 & 0.59 \\
\hline
\end{tabular}

Figure 3. Elemental composition of the core samples in the photographs of the prepared sample surface (all results are in wt.\%): (a) the elemental composition of the core samples 1.2 of the borehole No 1 (southern edge) in a cut of 3 m; (b) the same for the borehole No 2 (the top); (c) the same for the borehole No 3 (the northern edge) 
The calculation of the material and labor costs involved in the work on strengthening the rock massif at Orlovsky mine based on the estimated base of Kazakhstan showed that the total cost of 15 linear meters $(\mathrm{lm})$ amounted to 26.3 thousand U.S. dollars or 1.75 thousand U.S. dollars/lm.

\section{CONCLUSIONS}

According to the results of pilot tests, the developed massif injection technology for Orlovsky mine proved feasible, although some disadvantages of this technology were also observed.

The analysis conducted by the authors of the paper after the injection of massif at Orlovsky mine showed that cement slurry was gaining the necessary strength only after 8-12 hours, although, according to the technical characteristics, cement slurry setting process should begin within the range of $1.0-1.5$ hours and take up to 2.5 hours. However, cement slurry did not gain the necessary strength in 2-3 hours, and remained pliable. Adherence to the design cross section of a working contour in tunnel faces was observed only after the third cycle of rocks injection.

The research revealed unsafe working conditions for packers installation. Packers are short and, therefore, they had to be installed from the untimbered space in the working face. Therefore, it is recommended to use long selfwedging packers with "Techno DSI" LLC (Kemerovo) injection tubes. This packer design is disposable. A sealer is installed in an injection hole at different depths depending on a fracture of marginal massif (typically 1.0 to $1.5 \mathrm{~m}$ ). The packers can be installed from a safe place, as in this case, holes are drilled through wood in the top and edges of a working. This selfwedging packers may be installed in the middle of the hole, which allows to reduce a flow of solution through the working face and to achieve a more complete injection of fractured rocks.
It is also advisable to carry out pilot tests of the technology of tunneling in destroyed and fractured massif using two-component organic-resin "Blocksil" and twocomponent polyurethane resin "Blokpur" produced by "Techno DSI" LLC.

\section{ACKNOWLEDGEMENTS}

The authors express their sincere gratitude to engineering and technical personnel of Orlovsky mine of "Vostoktsvetmet" LLP for assistance in organizing and conducting field observations in mines.

\section{REFERENCES}

Butenko, I.T., Kara, V.V., Salnikov, V.K., \& Pihovich, I.J. (1978). Khimicheskiy sposob uprochneniya porod $v$ ochistnykh zaboyakh ugol'nykh shakht. Kyiv: Tehnika.

Feofanov, A.N. (2009). Likvidatsiya pustot starykh gornykh vyrabotok tamponirovaniyem. Proceedings UkrNIMI National Academy of Sciences of Ukraine, (4), 50-60.

Kiziyarov, O.L. (2004). Model' dlya issledovaniya parametrov tekhnologii kombinirovannogo uprochneniya krovli v lavakh. Collection of Scientific Works, (18), 87-91.

Kiziyarov, O.L. (2012). Obosnovaniye parametrov tekhnologii kombinirovannogo uprochneniya krovli v lavakh. Alchevsk: Donbaskyi derzhavnyi tekhnichnyi universytet.

Klimchuk, I.V. (2007). Opyt primeneniya polimernykh technologiy na gornodobyvayushchikh predpriyatiyakh Rossii. Mining, (4), 22-25.

Pravila obespecheniya promyshlennoy bezopasnosti dlya opasnykh proizvodstvennykh ob'ektov po khraneniyu $i$ pererabotke rastitel'nogo syr'ya. (2014). Astana: Ministerstvo po investitsiyam i razvitiyu Respubliki Kazakhstan.

STO NOSTROY 2.3.18-2011. (2011). Osvoenie podzemnogo prostranstva. Ukreplenie gruntov in'ektsionnymi metodami $v$ stroitel'stve. Moskva: Nostroy.

STO 17466563-001-2011. (2011). Rekomendatsii po in'ektsionnomu zakrepleniyu gruntov s primeneniem osobo tonkodispersnogo mineral'nogo vyazhushchego (OTDV) "MIKRODUR". Pravila proektirovaniya $i$ proizvodstva rabot. Moskva: MTSK.

\section{ABSTRACT (IN UKRAINIAN)}

Мета. Дослідження способу зміцнення зруйнованого та сильнотріщинуватого масиву гірських порід шляхом застосування ін'єкціювання мікроцементами при проходці гірничих виробок на Орлівській шахті ТОВ "Востокцветмет".

Методика. Виконано натурні дослідження щодо зміцнення масиву тампонажним розчином. Проведено контроль виконання ін'єкційних робіт шляхом контрольних випробувань кернів укріпленого грунту. Визначено фазовий склад зразків керна на рентгенівському дифрактометрі. Вивчена морфологія поверхні й виконаний локальний елементний аналіз зразків керна методом растрової електронної мікроскопії з енергодисперсійним мікроаналізом. Виконано розрахунок матеріально-трудових витрат на виконання робіт по зміцненню масиву гірських порід.

Результати. Досліджено спосіб зміцнення масиву тампонажним розчином на основі мікроцемента Rheocem®650 виробництва компанії BASF $з$ добавкою Rheobuild 2000PF у кількості 1-2\% від маси цементу. Встановлено, що витримування контуру виробки у прохідницьких забоях спостерігається після третього циклу робіт з ін'єкціювання гірських порід. Виявлені небезпечні умови робіт з установки пакерів. Рекомендовано провести дослідно-промислові випробування технології проходки гірничих виробок із застосуванням двокомпонентної органомінеральної смоли “Блоксил" із використанням саморозклинювальних довгих пакерів з ін'єкційними трубками.

Наукова новизна. Встановлено особливості застосування технології зміцнення зруйнованого та сильнотріщинуватого масиву гірських порід шляхом застосування ін'єкціювання мікроцементами. Виявлено кількісні показники вмісту мікроцемента в ін'єкційованому породному масиві.

Практична значимість. Розроблена й випробувана технологія зміцнення зруйнованого та сильнотріщинуватого масиву гірських порід ін'єкціюванням мікроцементами для умов Орлівської шахти.

Ключові слова: технологія ін'єкиіювання масиву, мікроџемент, пакери з ін'єкиійними трубками, проходка гірничих виробок, стійкість масиву гірських порід 


\section{ABSTRACT (IN RUSSIAN)}

Цель. Исследование способа укрепления разрушенного и сильнотрещиноватого массива горных пород путем применения инъекцирования микроцементами при проходке горных выработок на Орловской шахте ТОО "Востокцветмет".

Методика. Выполнены натурные исследования по укреплению массива тампонажным раствором. Проведен контроль выполнения инъекционных работ путем контрольных испытаний кернов укрепленного грунта. Определен фазовый состав образцов керна на рентгеновском дифрактометре. Изучена морфология поверхности и выполнен локальный элементный анализ образцов керна методом растровой электронной микроскопии с энергодисперсионным микроанализом. Выполнен расчет материально-трудовых затрат на выполнение работ по упрочнению массива горных пород.

Результаты. Исследован способ упрочнения массива тампонажным раствором на основе микроцемента Rheocem ${ }^{\circledR} 650$ производства компании BASF с добавкой Rheobuild 2000PF в количестве 1 - 2\% от массы цемента. Установлено, что выдерживание контура выработки в проходческих забоях наблюдается после третьего цикла работ по инъекцированию горных пород. Выявлены небезопасные условия работ по установке пакеров. Рекомендовано провести опытно-промышленные испытания технологии проходки горных выработок с применением двухкомпонентной органоминеральной смолы “Блоксил” с использованием саморасклинивающихся длинных пакеров с инъекционными трубками.

Научная новизна. Установлены особенности применения технологии укрепления разрушенного и сильнотрещиноватого массива горных пород путем применения инъекцирования микроцементами. Выявлены количественные показатели содержания микроцемента в инъекцированном породном массиве.

Практическая значимость. Разработана и испытана технология упрочнения разрушенного и сильнотрещиноватого массива горных пород инъекцированием микроцементами для условий Орловской шахты.

Ключевые слова: технология инъекцирования массива, микроцемент, пакеры с инъекционными трубками, проходка горных выработок, устойчивость массива горных пород

\section{ARTICLE INFO}

Received: 07 February 2017

Accepted: 28 February 2017

Available online: 30 March 2017

\section{ABOUT AUTHORS}

Leonid Krupnik, Doctor of Technical Sciences, Professor of the Department of Mining and Metallurgical Machinery and Equipment, Kazakh National Research Technical University named after K.I. Satpayev, 22 Satpayev St, 213, 050013, Almaty, Republic of Kazakhstan. E-mail: leonkr38@mail.ru

Yuriy Shaposhnik, Doctor of Technical Sciences, Senior Researcher of the Laboratory of Physical and Technical Geotechnology, Institute of Mining named after N.A. Chinakal of the Siberian Branch of the Russian Academy of Sciences, 54 Krasny Ave., 630091, Novosibirsk, Russia. E-mail: shaposhnikyury@mail.ru

Sergey Shaposhnik, Doctor of Technical Sciences, Professor of the Department of Geomechanics and Mining, D. Serikbaev East-Kazakhstan State Technical University, 69 Protozanov St, 70004, Ust-Kamenogorsk, Republic of Kazakhstan. E-mail: 1vg.nmu@mail.ru

Anton Konurin, Candidate of Technical Sciences, Senior Researcher of the Laboratory of Physical and Technical Geotechnology, Institute of Mining named after N.A. Chinakal of the Siberian Branch of the Russian Academy of Sciences, 54 Krasny Ave., 630091, Novosibirsk, Russia. E-mail: anton.konurin@gmail.com 